\title{
Article
}

Doi 10.5943/sif/5/1/8

\section{Diversity of endophytic fungi associated with Hedychium spicatum Ham ex Sm. and their antifungal activity against the phytopathogen Alternaria solani}

\author{
Sarma $\mathbf{P}^{1, *}$, Dkhar $\mathrm{MS}^{1}$, Kayang $\mathbf{H}^{1}$, Kumar $\mathbf{M}^{2}$, Dubey $\mathrm{NK}^{2}$ and \\ Raghuwanshi $\mathbf{R}^{3}$
}

${ }^{1}$ Microbial Ecology Laboratory, Department of Botany, North Eastern Hill University, Shillong, 793022
${ }^{2}$ Department of Botany, Banaras Hindu University, Varanasi, 221005
${ }^{3}$ Department of Botany, Mahila Mahavidyalaya, Banaras Hindu University, Varanasi, 221005

Sarma P, Dkhar MS, Kayang H, Kumar M, Dubey NK, Raghuwanshi R 2020 - Diversity of endophytic fungi associated with Hedychium spicatum Ham ex Sm. and their antifungal activity against the phytopathogen Alternaria solani. Studies in Fungi 5(1), 84-93, Doi 10.5943/sif/5/1/8

\begin{abstract}
Twenty eight strains of endophytic fungi including sterile mycelia were isolated from the leaf, rhizome and roots of Hedychium spicatum Ham ex. Sm. Majority of the endophytic fungi isolated belonged to the phylum Ascomycota which accounted of about 84\%. The endophytic assemblage was dominated by the class Sordariomycetes. Endophytic fungal genera such as Fusarium and Penicillium were found to be common to all the plant parts. Diversity of endophytic fungi was found to be highest in the roots $\left(\mathrm{H}^{\prime}=2.43\right)$. Mucor hiemalis, Penicillium sp., Penicillium expansum, $P$. simplicissimum, Phoma medicaginis, Trichoderma sp. and T. gamsii showed above $60 \%$ inhibition against the phytopathogen Alternaria solani.
\end{abstract}

Key words - Colonization frequency- diversity index - percentage inhibition

\section{Introduction}

The kingdom fungi plays important role in the ecosystem. It includes about 1.5 million species and a vast majority are still to be identified (Hawksworth 2001). The kingdom includes parasites, saprophytes and mutualists. The relationship between plant and fungi is a complex and ancient one, however fewer than $10 \%$ of fungi are known to colonize plants (Knogge 1996). Plant pathogenic fungi represent relatively a small group of those fungi that are associated with the living plants. Majority of the fungi are saprophytes that depend on dead organic matters for nutrition and others are symbionts and as cryptic colonizers of plants known as 'Endophytes'.

The term endophyte was coined by De Bary in 1866. This term is referred to a wide range of organisms residing within the plant. Fungal endophytes are reported to be present in almost all the plants (Larran et al. 2002). They are known to provide resistance to the host against many phytopathogens and provide stress tolerance (Azevedo et al. 2000, Sturz\& Nowak 2000).Vogl (1898) first isolated and cultured asymptomless endophytes from seeds of Lolium temulentum. Based on their nature, endophytic fungi are categorized into three groups viz. pathogens of another host plant that do not cause infections in other plants in which they reside, microbes which are non pathogenic and pathogens that have been rendered nonpathogenic but are still capable of 
colonization by selection methods or genetic alteration (Backman \& Sikora 2008). Most fungal endophytes isolated to date have been identified as ascomycetes and their asexual morphs; however Rungjindamai et al. (2008) showed that several endophytic fungi may also be basidiomycetes. Endophytic fungi have been found in most plant organs; they can enter the plant through the roots and remain there or become systemic and colonize stem, leaves and even flowers and fruits. However, roots are not the only way of entrance; many phyllosphere endophytes enter the plant trough stomata or wounds (McCully 2001, Schulz \& Boyle 2006, Danhorn \& Fuqua 2007). While some endophytic fungi appear to be ubiquitous (e.g. Fusarium spp., Alternaria spp., Pestalotiopsis spp., Aspergillus spp, Botryosphaeria spp.) others apparently present host specificity and/or host preference (Petrini 1996, Suryanarayanan \& Kumar 2000, Schulz \& Boyle 2006, Hu et al. 2007, Slippers \& Wingfield 2007, Pang et al. 2008, Toju et al. 2013).

The present work was conducted to study the endophytic fungal diversity of Hedychium spicatum Ham ex Sm and antifungal activity of the selected endophytic fungi against the pathogen Alternaria solani.

Alternaria solani is known to cause various diseases in the commercially important plant tomato such as early blight (foliage), collar rot (basal stem of seedlings), stem lesions (stem of adult plants) and fruit rot (fruits). Early blight is the most destructive of all of the other diseases.

The plant Hedychium spicatum belongs to the family Zingiberaceae. It is found from Himachal Pradesh to Arunachal Pradesh, at altitudes of 1800-2800 m. It grows to around 1-1.5 m, with leafy stems. Flowers are fragrant, white with an orange-red base, appearing in a dense spike, 15-25 cm, at the top of the stem. The rootstock is carminative, expectorant, stimulant, stomachic and tonic. It is useful in the treatment of liver complaints, and is also used in treating fevers, vomiting, diarrhea, inflammation, pains and snake bite. The aim of this study is to identify the fungal endophytes using culture dependent techniques and to study the antifungal activity of selected endophytes against the phytopathogen $A$. solani.

\section{Materials \& Methods}

\section{Study site and collection of plant material}

The plant materials of Hedychium spicatum were collected from Mawlai, East Khasi Hills, The study site Mawlai is situated at an altitude of $1400 \mathrm{msl}$ and lies at $25^{\circ} 36^{\prime} 41.2^{\prime \prime} \mathrm{N}$ latitude and $91^{\circ} 53$ ' 59.2" E longitude.

\section{Culture, identification and isolation}

Leaf, stem and roots were collected aseptically from the plant Hedychium spicatum and were processed within 24 hours of collection following the methods of Suryanarayanan et al. (2003).

Potato dextrose agar medium (PDA) was used for the isolation and identification of endophytic fungi. The samples were thoroughly washed in tap water and were cut into small pieces ( $5 \mathrm{~mm}$ for leaf, $1 \mathrm{~cm}$ for stem and root). To eliminate the epiphytic microorganisms all the samples were surface sterilized by immersing in $70 \%$ alcohol for 1-3 minutes, followed by Sodium hypochlorite (4\% available chlorine) for 3-5 minutes and again washed in alcohol for 2-5 seconds before a final rinse in distilled water. The samples were dried in laminar airflow before placing them in the Petri-dish containing PDA medium amended with streptomycin sulphate $(100 \mathrm{mg} / \mathrm{L})$. The Petri-dishes were incubated for $7-10$ days in incubator at $25 \pm 2^{\circ} \mathrm{C}$. Hyphae from the emerging colonies were again subcultured in Czapek Dox Agar media for 5-7 days to obtain pure culture. Identification of the isolated endophytic fungi was carried out based on their morphological and reproductive structures using standard manuals (Ellis 1976, Domsch et al. 1980, Barnett \& Hunter 1998) and websites, www.indexfungorum.com and www.mycobank.com.

\section{Data analysis}

The colonization frequency (CF \%) of each endophytic fungi was calculated following the method of Hata \& Futai (1995). 


$$
\mathrm{CF}(\%)=\left(\mathrm{N}_{\mathrm{col}} / \mathrm{N}_{\mathrm{t}}\right) \times 100
$$

Where:

$\mathrm{N}_{\mathrm{col}}=$ the number of segments colonized by each endophytic fungi

$\mathrm{N}_{\mathrm{t}}=$ the total number of segments observed

Shannon- Wiener diversity index and Simpsons's index was calculated by the formulae:

Shannon- Wiener diversity index $=-\Sigma[(\mathrm{pi}) \mathrm{x} \ln (\mathrm{pi})]$

Simpson's dominance index $=\Sigma(\mathrm{pi})^{2}$

Where $\mathrm{pi}=(\mathrm{n} / \mathrm{N}), \mathrm{pi}=$ proportion of colonization of the $i$ th species in a sample.

Jaccard's index $(\mathrm{JI} \%)=\mathrm{c} /(\mathrm{a}+\mathrm{b}-\mathrm{c}) \times 100$

$\mathrm{a}=$ No. of species in community 1

$\mathrm{b}=$ No. of species in community 2

$\mathrm{c}=$ No. of species common between the two assemblages.

Shannon's Diversity and Simpsons dominance indices were calculated using the software PAST

\section{Antimicrobial activity}

Antimicrobial activity of the endophytic fungi against the phytopathogen Alternaria solani was studied following the method of Skidmore \& Dickinson (1976). Fourteen endophytic fungi were selected to test their antimicrobial activity against the phytopathogen Alternaria solani. Discs of pathogen and the antagonist (5 mm diameter each) were placed diametrically opposite to each other on the Petri dish containing PDA medium. The plates were incubated at $25 \pm 2^{\circ} \mathrm{C}$ for $7-9$ days Three replicates were maintained and pure cultures of the pathogen and endophytic fungi were maintained as controls. The growth of antagonist and pathogen colonies were measured after 5 days of incubation at regular intervals of 24 hours till the $8^{\text {th }}$ day. The percentage inhibition of the pathogen was calculated using the following equation based on Keshavachandran et al. (2007).

$$
\% \text { inhibition }=\frac{\mathrm{Y}-\mathrm{Z}}{\mathrm{Y}} \times 100
$$

Where:

$\mathrm{Y}=$ mycelial growth of the pathogen in pure culture (control)

$\mathrm{Z}=$ mycelial growth of the pathogen along with the antagonist

\section{Results}

\section{Diversity}

A total of 28 strains of endophytic fungi including sterile mycelia were isolated from the leaf, rhizome and root of Hedychium spicatum. Highest number of species were isolated from the root (16 species) followed by the leaf (15 species) and the stem (13 species). However not much difference was observed between the numbers of species isolated from each part of the plant. 84.00\% of the isolated endophytic fungi belonged to Ascomycota followed by Zygomycota and Oomycota which accounted for $8.00 \%$ each (Fig. 1).The isolated fungi belonged to the classes Dothideomycetes, Eurotiomycetes, Mucoromycetes, Saccharomycetes and Sordariomycetes (Table 1). Sordariomycetes was found to be the predominant class in the endophytic assemblage of the plant (Fig. 2). Endophytic fungi such as Fusarium sp.1, Fusarium sp.2 and Penicillium simplicissimum were found to be common to all the plant parts. Juxtiphoma eupyrena was found to be dominant in the leaves with colonization frequency of $12.50 \%$. Fusarium sp.1 and Fusarium sp.2 were found to be dominant in the rhizome with colonization frequency of $7.64 \%$ and in the roots highest dominance was exhibited by Fusarium sp.2 with colonization frequency of $13.89 \%$ (Table 2).

The genera specific to the leaves were Acremonium, Alternaria, Arthrinium, Cladosporium, Colletotrichum, Globisporangium and Pyhtium. Four genera were found to be specific to the 
rhizomes which were Absidia, Ilyonectria, Mucor and Trichoderma. Humicola, Meyerozyma and Nectria were present in the underground parts such as rhizome and roots. (Table 2).

The diversity indices of the endophytic assemblage of $H$. spicatum are shown in Table 3 . Higher the values of Shannon's diversity index (1.5-3.5) and closer the Simpson's diversity index to 1 the more diversified is the microbial assemblage. Diversity of endophytic fungi was found to be highest in the roots $\left(H^{\prime}=2.43\right)$ followed by the rhizome $\left(H^{\prime}=2.42\right)$ and the leaf $(H=2.41)$. Similarly Simpson's diversity index $(0.88-0.89)$ was found to be almost same in all the tissues which show a great degree of diversity of endophytic community in all the tissues. Simpson's Dominance Index (D) ranged between 0.11-0.12 which indicates that the individuals belonged to diverse genera and species. Jaccard's index showed that the species similarity of the endophytic community of the leaf tissue overlapped the rhizome tissue by $15.15 \%$, species composition of rhizome tissue overlapped the root tissue by $23.68 \%$ and the species composition of the leaf overlapped the root by $18.42 \%$.

\section{Antifungal activity}

Fourteen endophytic fungi were tested for their antifungal activities. Among them 10 strains showed more than $50 \%$ inhibition towards the phytopathogen A. solani. It was observed that Trichoderma sp. grew faster than other isolates in PDA and showed maximum inhibition towards A. solani with $66.30 \%$. Overall the ranks Trichoderma and Penicillium showed inhibition of $60 \%$ and above. Apart from these ranks the other endophytes which showed similar percentage inhibitions were Mucor hiemalis and Phoma medicaginis. Absidia sp, Acremonium cerealis, Fusarium sp. 1 and Meyerozyma caribbica inhibited the pathogen by 50-59\%. The least inhibition was shown by Juxtiphoma eupyrena with approximately 26.67\% (Table 4).

\section{Discussion}

The present work reported the isolation and identification of cultureable endophytic fungi from different plant tissues and the antimicrobial activity of the selected endophytic fungi against the pathogen A. solani using Potato Dextrose Agar media (PDA).

Majority of the isolated strains belonged to the phylum Ascomycota. Ascomycota was found to be the most dominant phylum in all the plant parts and also accounted about $84.00 \%$ of the assemblage which is in accordance to the findings of Park et al. (2017). Sordariomycetes was the predominant class with $40 \%$ of the endophytic fungi as shown from the findings of Li et al. (2016). The genera Fusarium and Penicillium were common to all the plant parts however, the genus Fusarium was found to be more dominating in the rhizome and the roots (Imazaki \& Kadota 2015, Potshangbam 2017). Species of Fusarium have also been isolated from the healthy rhizomes of Dioscorea zingiberensis (Zhang et al. 2010). Some isolated endophytic fungi showed specificity for particular tissues types. This was also evident from previous studies which showed specificity of endophytic fungi for particular tissue types (Errasti et al. 2010, Sánchez-Márquez et al. 2010, Wearn et al. 2012). The genus Acremonium which has been found specific to the leaves is also reported as a major grass endophyte (White 1987), it also has a wide host range among non grass plants which includes Vitis vinifera (Arnone et al. 2009), Rhizophora apiculata(Rukachaisirikul et al. 2012), Actinidia macrosperma (Lu et al. 2012) and Bursera simaruba (Gonzalez et al. 2016).Humicola sp. and Ilyonectria sp. have also been isolated from Fragaria vesca (Yokoya et al. 2017) and the specificity of Humicola to the roots has also been reported by the same authors. The endophytes such as Juxtiphoma eupyrena isolated from the plant are known to be pathogenic to several plant species. It was observed that Shannon's diversity index was higher in the rhizome and roots as compared to the leaves. Previous studies have also reported similar results (Rivera-Oduna et al. 2011, Jin et al. 2013). The greater diversity of endophytic fungi in the underground parts specifically the rhizome and roots is due to the presence of soil borne fungi which are more diversified than the air borne fungi which colonize the aerial parts (Jin et al. 2013).

Fourteen endophytic fungi were tested for their antimicrobial activities against the pathogen Alternaria solani out of which maximum inhibition percentage was shown by the ranks 
Trichoderma and Penicillium. The genus Trichoderma is also a well known biocontrol agent with outstanding capability to interact with plant and plant pathogens (Spiegel \& Chet 1998, Mukherjee et al. 2012) has the ability to efficiently compete for space and nutrient with the target pathogen thus depriving the pathogen of its basic requirements (Siameto et al. 2010). The efficacy of $T$. gamsii in controlling growth of phytopathogens in vitro have been reported by Chen et al. (2016) which is also attributed to its efficiency in competing with the target pathogen. The mycoparasitism process of Trichoderma sp. involves the lysis of protoplasm of hyphae, endoconidia and chlamydospores as observed by Ramanujam et al. (2002) in case of $T$. harzianum and $T$. viride against Thielaviopsis paradoxa. Trichoderma sp also produce volatile organic compounds such as alcohols, Ketones, alkanes, furanes, pyrones and terpenes which have varying degree of antagonistic activity against pathogens (Stoppacher et al. 2010). Members of the genus Penicillium have also shown good inhibitory effect in vitro which may be due to production of the secondary metabolite $\beta$-1-3- glucanase, a cell lytic enzyme which inhibits the growth of pathogen (Druvefors et al. 2002). Higher percentage of inhibition was also shown by the strains belonging to the genera of Acremonium, Absidia, Fusarium and Meyerozyma. Acremonium sp. isolated as an endophyte from Zingiber officinale have been found to be an antagonist against soft rot pathogen Pythium myriotylum (Anisha \& Radhakrishnan 2015).Absidia sp. is also known to show antagonistic activity against the rice pathogen Magnaporthe grisea (Atugala \& Deshappriya 2015). Certain species of Fusarium is known to control the root rot disease in Pisum sativum and Meyerozyma caribbica is known to possess antifungal activity against Colletotrichum gloeosporioides (Sisic et al. 2017, Bautista-Rosales et al. 2013). Certain species of Fusarium are also known to suppress several soil borne pathogen (Macia-Vicente et al. 2008) andAlternaria solani is one of them (Chaerani \& Voorrips 2006) which is the reason it may show inhibitiory activity in vitro. The endophytic fungi showing high levels of inhibitory activity against $A$. solani could be used as potential biocontrol agents against diseases caused by the phytopathogen. Further studies are required to throw light into other prospects of these endophytes.

Table 1 List of endophytic fungal strains isolated from the tissues of Hedychium spicatum

\begin{tabular}{|c|c|c|c|c|c|}
\hline $\begin{array}{l}\text { Sl. } \\
\text { No. }\end{array}$ & Endophytes & Family & Order & Class & Phylum \\
\hline $\begin{array}{l}1 \\
2\end{array}$ & $\begin{array}{l}\text { Globisporangium intermedium } \\
\text { Pyhtium aphanidermatum }\end{array}$ & Pythiaceae & Peronosporales & Incertae sedis & Oomycota \\
\hline $\begin{array}{l}3 \\
4\end{array}$ & $\begin{array}{l}\text { Absidia sp. } \\
\text { Mucor hiemalis }\end{array}$ & $\begin{array}{c}\text { Cunninghamellaceae } \\
\text { Mucoraceae }\end{array}$ & Mucorales & Mucoromycetes & Zygomycota \\
\hline $\begin{array}{l}5 \\
6\end{array}$ & $\begin{array}{l}\text { Cladosporium cladosporioides } \\
\text { C. macrocarpum }\end{array}$ & Cladosporiaceae & Capnodiales & & \multirow{16}{*}{ Ascomycota } \\
\hline 7 & Alternaria alternata & Pleosporaceae & & & \\
\hline 8 & Juxtiphom a eupyrena & & & & \\
\hline 9 & Phoma medicaginis & & & Dothideomycetes & \\
\hline 10 & Penicillium sp. & Didvmellaсеае & Pleosporales & & \\
\hline 11 & P. expansum & Diaymenacede & & & \\
\hline 12 & P. simplicissimum & & & & \\
\hline 13 & P. spinulosum & & & & \\
\hline 14 & Meyerozyma caribbica & Debaryomycetaceae & Saccharomycetales & Saccharomycetes & \\
\hline 15 & Colletotrichum sp. & Glomerallaceae & Glomerellales & \multirow{7}{*}{ Sordariomycetes } & \\
\hline $\begin{array}{l}16 \\
17\end{array}$ & $\begin{array}{l}\text { Acremonium cerealis } \\
\text { Ilyonectria sp. }\end{array}$ & Incertae sedis & \multirow{6}{*}{ Hypocreales } & & \\
\hline 18 & Fusarium sp.1 & & & & \\
\hline 19 & Fusarium sp.2 & Nectriaceae & & & \\
\hline 20 & F. redolens & & & & \\
\hline 21 & Nectria inventa & & & & \\
\hline $\begin{array}{l}22 \\
23\end{array}$ & $\begin{array}{l}\text { Trichoderma sp. } \\
\text { T. gamsii }\end{array}$ & Hypocreaceae & & & \\
\hline
\end{tabular}


Table 1 Continued.

\begin{tabular}{|c|c|c|c|c|c|}
\hline $\begin{array}{l}\text { Sl. } \\
\text { No. }\end{array}$ & Endophytes & Family & Order & Class & Phylum \\
\hline 24 & Humicola fuscoatra & Chaetomiaceae & Sordariales & & \\
\hline 25 & Arthrinium arundinis & Apiosporaceae & Incertae sedis & & \\
\hline
\end{tabular}

Table 2 Percentage colonization frequency of endophytic fungal strains from different tissues of $H$. spicatum

\begin{tabular}{clccc}
\hline Sl. & \multicolumn{1}{c}{ Endophytes } & \multicolumn{3}{c}{ CF (\%) } \\
\cline { 2 - 4 } No. & & Leaf & Rhizome & Root \\
\hline 1 & Absidia sp. & - & 0.69 & - \\
2 & Acremonium cerealis & 1.39 & - & - \\
3 & Alternaria alternata & 1.39 & - & - \\
4 & Arthrinium arundinis & 2.78 & - & - \\
5 & Cladosporium cladosporioides & 2.78 & - & - \\
6 & C. macrocarpum & 1.39 & - & - \\
7 & Colletotrichum sp. & 1.39 & - & - \\
8 & Fusarium sp.1 & 4.17 & 7.64 & 2.08 \\
9 & Fusarium sp.2 & 1.39 & 7.64 & 13.89 \\
10 & F. redolens & - & - & 0.69 \\
11 & Globisporangium intermedium & 2.78 & - & - \\
12 & Humicola fuscoatra & - & - & 3.47 \\
13 & Ilyonectria sp. & - & 2.78 & - \\
14 & Juxtiphoma eupyrena & 12.50 & - & 3.47 \\
15 & Meyerozyma caribbica & - & - & 1.39 \\
16 & Mucor hiemalis & - & 2.08 & - \\
17 & Nectria inventa & - & - & 0.69 \\
18 & Penicillium sp. & - & 2.78 & 1.39 \\
19 & P. expansum & - & 0.69 & 1.39 \\
20 & P. simplicissimum & 1.39 & 3.47 & 4.17 \\
21 & P. spinulosum & - & - & 0.69 \\
22 & Phoma medicaginis & 5.56 & - & 2.78 \\
23 & Pythium aphanidermatum & 1.39 & - & - \\
24 & Trichoderma gamsii & - & 4.86 & 3.47 \\
25 & Trichoderma sp. & - & 6.25 & - \\
26 & Mycelia sterilia (Black) & 8.33 & 2.08 & 3.47 \\
27 & Mycelia sterilia (White) & 4.17 & 2.08 & 4.17 \\
28 & Mycelia sterilia (Yellow) & - & 6.94 & 2.08 \\
\hline$-=$ absent & & &
\end{tabular}

Table 3 Diversity indices of endophytic fungi from the tissues of $H$. spicatum

\begin{tabular}{lccc}
\hline \multicolumn{1}{c}{ Diversity indices } & Leaf & Rhizome & Root \\
\hline Shannon Weiner's index (H) & 2.41 & 2.42 & 2.43 \\
Simpson's Dominance index (D) & 0.12 & 0.11 & 0.12 \\
Simpson's Diversity index (1-D) & 0.88 & 0.89 & 0.88 \\
\hline
\end{tabular}

Table 4 Antifungal activity of selected endophytic fungal strains against the pathogen Alternaria solani

\begin{tabular}{|c|c|c|c|c|}
\hline \multirow[b]{2}{*}{$\begin{array}{l}\text { Sl. } \\
\text { No. }\end{array}$} & \multirow[b]{2}{*}{ Endophytes } & \multicolumn{3}{|c|}{ Pathogen } \\
\hline & & $\begin{array}{l}\text { Growth in } \\
\text { control (mm) }\end{array}$ & $\begin{array}{l}\text { Growth with } \\
\text { antagonist (mm) }\end{array}$ & $\begin{array}{l}\text { Percentageinhibitio } \\
\text { n (\%) }\end{array}$ \\
\hline 1 & Absidia sp. & 90 & $37.33 \pm 3.71$ & $58.52 \pm 4.12$ \\
\hline 2 & Acremonium cerealis & 70 & $33.33 \pm 2.91$ & $52.38 \pm 4.15$ \\
\hline
\end{tabular}


Table 4 Continued.

\begin{tabular}{llccc}
\hline \multirow{2}{*}{$\begin{array}{c}\text { Sl. } \\
\text { No. }\end{array}$} & \multicolumn{1}{c}{ Endophytes } & $\begin{array}{l}\text { Pathogen } \\
\text { Growth in } \\
\text { control (mm) }\end{array}$ & $\begin{array}{l}\text { Growth with } \\
\text { antagonist }(\mathbf{m m})\end{array}$ & $\begin{array}{l}\text { Percentage } \\
\text { inhibition (\%) }\end{array}$ \\
\hline 3 & Cladosporium & 70 & $36.67 \pm 0.33$ & $47.62 \pm 0.48$ \\
& cladosporioides & & & \\
4 & Fusarium sp. 1 & 70 & $29.33 \pm 0.67$ & $58.10 \pm 0.95$ \\
5 & Fusarium sp. 2 & 90 & $49.33 \pm 0.33$ & $45.19 \pm 0.37$ \\
6 & Juxtiphoma eupyrena & 70 & $51.33 \pm 1.86$ & $26.67 \pm 2.65$ \\
7 & Meyerozyma caribbica & 70 & $34.33 \pm 0.33$ & $50.95 \pm 0.48$ \\
8 & Mucor hiemalis & 75 & $28.33 \pm 1.67$ & $62.22 \pm 2.22$ \\
9 & Penicillium sp & 50 & $33.33 \pm 4.41$ & $33.33 \pm 8.82$ \\
10 & P. expansum & 50 & $18.33 \pm 1.67$ & $63.33 \pm 3.33$ \\
11 & P. simplicissimum & 75 & $29.33 \pm 5.17$ & $60.89 \pm 6.90$ \\
12 & Phoma medicaginis & 70 & $26.00 \pm 2.08$ & $62.86 \pm 2.97$ \\
13 & Trichoderma gamsii & 80 & $29.33 \pm 2.33$ & $63.33 \pm 2.92$ \\
14 & Trichoderma sp. & 90 & $30.33 \pm 0.88$ & $66.30 \pm 0.98$ \\
\hline
\end{tabular}

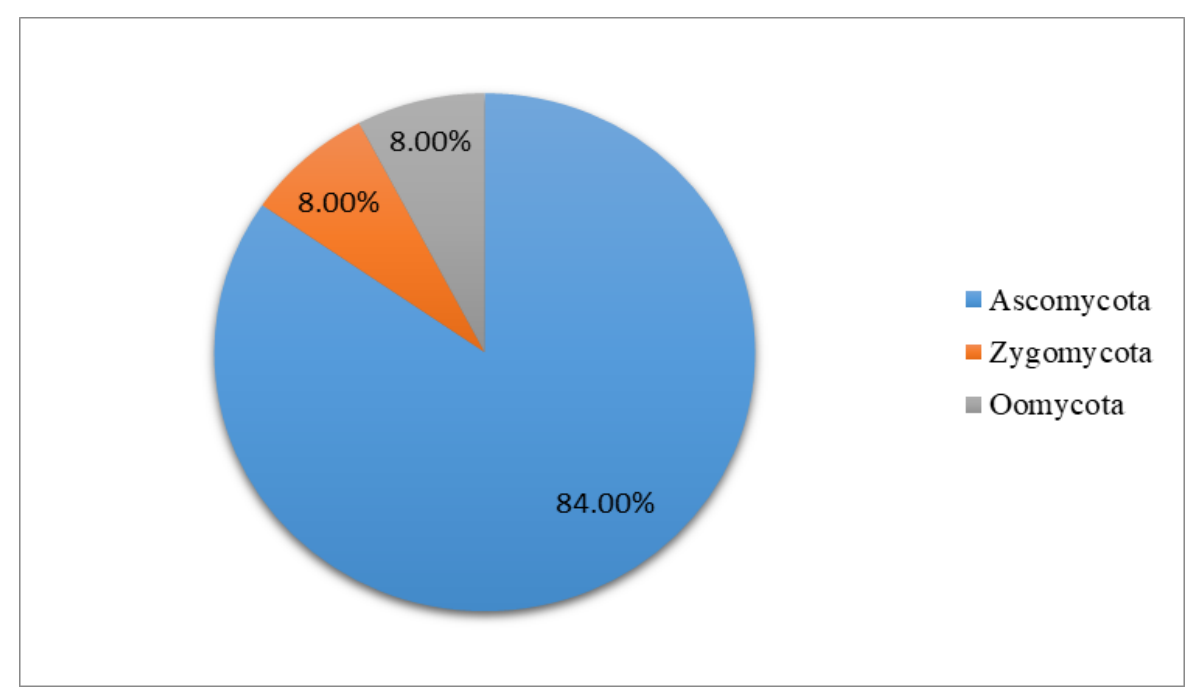

Fig. 1 - Percentage of occurrence of endophytic fungi from different phyla

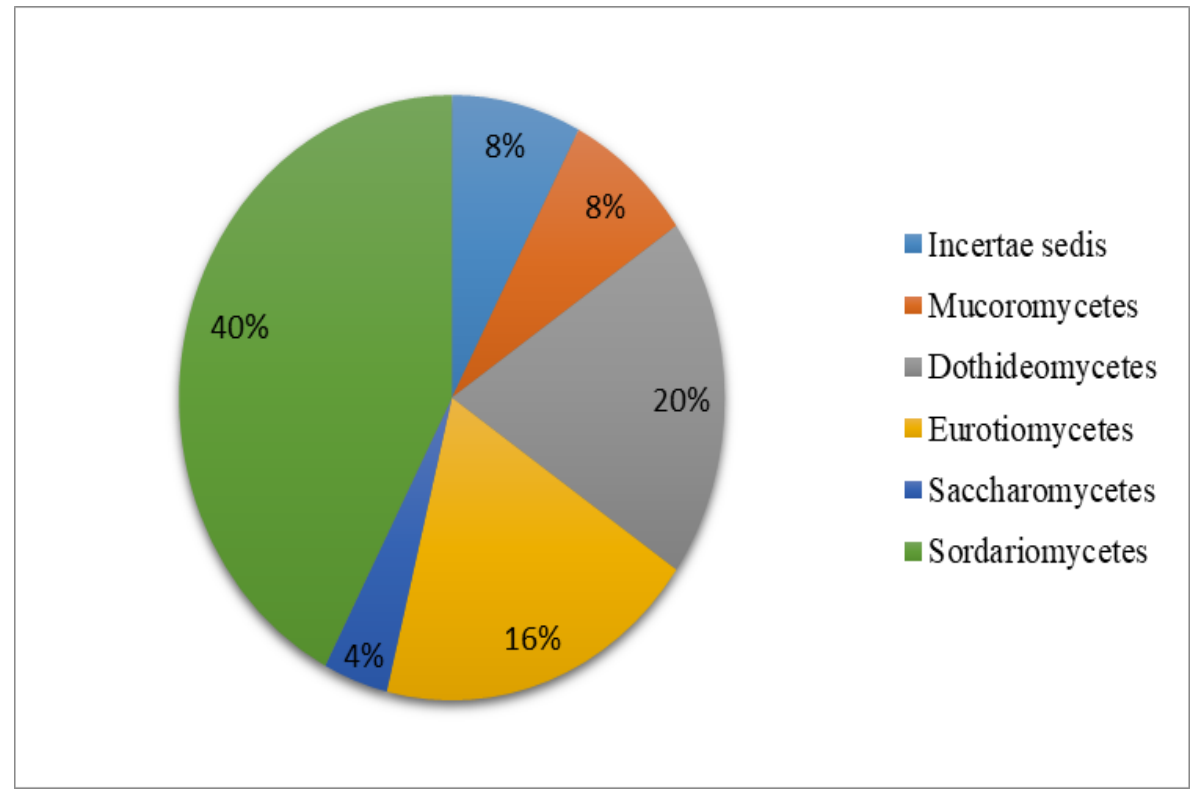

Fig. 2 - Percentage of occurence of endophytic fungi from different classes 


\section{Acknowledgement}

The authors are grateful to the head of the Department, Botany, North Eastern Hill University, Shillong for providing necessary laboratory facilities, DBT-infrastructure and CAS for providing necessary instruments and DBT for providing financial assistance.

\section{References}

Anisha C, Radhakrishnan CK. 2015 - Gliotoxin-Producing Endophytic Acremonium sp. from Zingiber officinale Found Antagonistic to Soft Rot Pathogen Pythium myriotylum. Applied Biochemistry and Biotechnology 175, 3458-3467.

Arnone A, Assante G, Bava A, Dallavalle S, Nasini G. 2009 - Acremines H-N, novel prenylated polyketide metabolites produced by a strain of Acremonium byssoidesq. Tetrahedron 65, 786791.

Atugala DM, Deshappriya N. 2015 - Effect of endophytic fungi on plant growth and blast disease incidence of two traditional rice varieties. Journal of the National Science Foundation of Sri Lanka 43, 173-187.

Azevedo JL, Jr Maccheroni W, Pereira JO, Araujo WL. 2000 - Endophytic microorganisms: a review on insect control and recent advances on tropical plants. Electronic Journal of Biotechnology 3, 41-65.

Backman PA, Sikora RA. 2008 - Endophytes: an emerging tool for biological control. Biological Control 46, 1-3

Barnett HL, Hunter BB. 1998 - Illustrated Genera of Imperfect Fungi. New York: MacMillan Publ. Co.

Bautista-Rosales PU, Servin-Villegas RS, Santoyo-Calderon M, Ragzzo-Sanchez JA. 2013 Action mechanisms of the yeast Meyerozyma caribbica for the control of phytopathogen Colletotrichum gloeosporioides in mangoes. Biological control 65, 293-301.

Chaerani R, Voorrips RE. 2006 - Tomato early blight (Alternaria solani): the pathogen, genetics, and breeding for resistance. Journal of General Plant Pathology 72, 335-347.

Chen JL, Sun SZ, Miao CP, Wu K et al. 2015 - Endophytic Trichoderma gamsii YIM PH30019: a promising biocontrol agent with hyperosmolar, mycoparasitism, and antagonistic activities of induced volatile organic compounds on root-rot pathogenic fungi of Panax notoginseng. Journal of Ginseng Research 40, 315-324.

Danhorn T, Fuqua C. 2007 - Biofilm formation by plant-associated bacteria. Annual Review of Microbiology 61, 401-422.

DeBary A.1866 - Morphologie und Physiologie der Pilze, Flechten und Myxomyceten. Hofmeister's Handbook of physiological Botany, Vol. 2, Leipzig.

Domsch KH, Gams W, Anderson TH. 1980 - Compendium of soil fungi. London, England: Academic Press. 865 p.

Druvefors U, Jonsson N, Boysen ME, Schnürer J. 2002 - Efficacy of the biocontrol yeast Pichia anomala during long-term storage of moist feed grain under different oxygen and carbon dioxide regimens. FEMS Yeast Research 2, 389-394

Ellis MB. 1976 - Dematiaceous Hyphomycetes. CAB International, Oxon. pp 507.

Errasti A, Carmaran C, Novas V. 2010 - Diversity and significance of fungal endophytes from living stems of naturalized trees from Argentina. Fungal Diversity 41, 29-40.

Gonzalez MC, Glenn AE, Hanlin RT, Rubalcava MLM et al. 2016 -Acremonium camptosporum isolated as an endophyte of Bursera simaruba from Yucatan Peninsula, Mexico. Mycotaxon 131, 211-225.

Hata K, Futai K. 1995 - Endophytic fungi associated with healthy pine needles infested by the pine needle gall midgeThecodiplosis japonensis. Canadian Journal of Botany 73, 384-390.

Hawksworth DL. 2001 - The magnitude of fungal diversity: The 1.5 million species estimate revisited. Mycological research 105, 1422-1432. 
Hu HL, Jeewon R, Zhou DQ, Zhou TX, Hyde KD. 2007 - Phylogenetic diversity of endophytic Pestalotiopsis species in Pinus armandii and Ribes spp.: evidence from rDNA and ü-tubulin gene phylogenies. Fungal Diversity 24, 1-22.

Imazaki I, Kadota I. 2015 - Molecular phylogeny and diversity of Fusarium endophytes isolated from tomato stems. FEMS Microbiology Ecology 9, 1-16.

Jin H, Yan Z, Liu Q, Yang X, Chen J, Qin B. 2013 - Diversity and dynamics of fungal endophytes in leaves, stems and roots of Steller achamaejasme L. in northwestern China. Antonie van Leeuwenhoek 104, 949-963.

Keshavachandran R, Nazeem PA, John PS, Peter KV. 2007 - Reecent trends in horticultural biotechnology. New Indian Publisher, New Delhi, pp. 967.

Knogge W. 1996 - Fungal infection of plants. The Plant Cell 8, 1711-1722.

Larran S, Perelló A, Simo MR, Moreno V. 2002 - Isolation and analysis of endophytic microorganisms in wheat (Triticum aestivum L.) leaves. World Journal of Microbiology and Biotechnology 18, 683-686.

Li P, Wu Z, Liu T, Wang Y. 2016 - Biodiversity, Phylogeny, and Antifungal Functions of Endophytic Fungi Associated with Zanthoxylum bungeanum. International Journal of Molecular Sciences 17, 1541.

Lu Y, Chen C, Chen H, Zhang J, Chen W. 2012 - Isolation and identification of endophytic fungi from Actinidia macrosperma and investigation of their bioactivities. Evidence- Based Complementary and Alternative Medicine 1-8.

Macia-Vicente JG, Jansson HB, Abdullah SK, Descals E et al. 2008 - Fungal root endophytes from natural vegetation in Mediterranean environments with special reference to Fusarium spp. FEMS Microbiology Ecology 64, 90-105.

McCully ME. 2001 - Niches for bacterial endophytes in crop plants: a plant biologist's view. Aust Journal of Plant Physiology 28, 983-990.

Mukherjee M, Mukherjee PK, Horwitz BA, Zachow C et al. 2012 - Trichoderma plant pathogen interactions: advances in genetics of biological control. Indian Journal of Microbiology 52, 522-529.

Pang KL, Vrijmoed LLP, Goh TK, Plaingam N, Jones EBG. 2008 - Fungal endophytes associated with Kandelia candel (Rhizophoraceae) in Mai Po Nature Reserve, Hong Kong. Botanica Marina 51, 171-178.

Park YH, Kim Y, Mishra RC, Bae H. 2017 - Fungal endophytes inhabiting Mountain cultivated Ginseng (Panax ginseng Meyer): Diversity and biocontrol activity against ginseng pathogens. Scientific Reports 7: 16221.

Petrini O. 1996 - Ecological and physiological aspects of host specificity in endophytic fungi. In: Redlin SC, Carris LM (eds). Endophytic Fungi in grasses and woody plants. APS Press, St. Paul, pp. 87-100.

Potshangbam M, Devi SI, Sahoo D, Strobel GA. 2017 - Functional characterization of endophytic fungal community associated with Oryza sativa L. and Zea mays L. Frontiers in Microbiology 8, 1-15.

Ramanujam B, Nambiar KKN, Rohini I, Iyer R. 2002 - Hyphal interaction studies between Thielaviopsis paradoxa and its antagonistic fungi. Indian Phytopathogen 5, 516-518.

Rivera-Orduña FN, Suarez-Sanchez RA, Flores-Bustamante ZR, Gracida-Rodriguez JN, FloresCotera LB. 2011 - Diversity of endophytic fungi of Taxus globosa (Mexican yew). Fungal Diversity47, 65-74.

Rukachaisirikul V, Rodglin A, Sukpondma Y, Phongpaichit S et al. 2012 - Phthalide and isocoumarin derivatives produced by an Acremonium sp. isolated from a mangrove Rhizophora apiculata. Journal of Natural Products 75, 853-858.

Rungjindamai N, Pinruan U, Choeyklin R, Hattori T, Jones EBG. 2008 - Molecular characterization of basidiomycetous endophytes isolated from leaves, rachis and petioles of the oil palm, Elaeis guineensis, in Thailand. Fungal Diversity 33, 139-162 
Sánchez-Márquez S, Bills GF, Domínguez-Acuña L, Zabalgogeazcoa I. 2010 - Endophytic mycobiota of leaves and roots of the grass Holcus lanatus. Fungal Diversity 41, 115-123.

Schulz B, Boyle C. 2006 - What are endophytes? In: Schulz B, Boyle CJ, Sieber TN (eds) Microbial root endophytes. Springer, Berlin,pp 1-13

Siameto EN, Okoth S, Amugune NO, Chege NC. 2010 - Antagonism of Trichoderma harzianum isolates on soil borne plant pathogenic fungi from Embu District, Kenya. Journal of Yeast and Fungal Research 3, 47-54.

Sisic A, Becanovic J, Finckh MR. 2017- Endophytic Fusarium equiseti stimulates plant growth and reduces root rot disease of pea (Pisum sativum L.) caused by Fusarium avenaceum and Peyronella eapinodella. European Journal of Plant Pathology148, 271-282.

Skidmore AM, Dickinson CM. 1976 - Colony interactions and hyphal interference between Septoria nodorum and phylloplane fungi. Transactions of British Mycological Society 66, 57-64.

Slippers B, Wingfield MJ. 2007- Botryosphaeriaceae as endophytes and latent pathogens of woody plants: diversity, ecology and impact. Fungal Biology Reviews 21, 90-106.

Spiegel Y, Chet I. 1998 - Evaluation of Trichoderma spp. as a biocontrol agent against soil borne fungi and plant-parasitic nematodes in Israel. Integrated Pest Management Reviews 3, 169175.

Stoppacher N, Kluger B, Zeilinger S, Krska R, Schuhmacher R. 2010 - Identification and profiling of volatile metabolites of the biocontrol fungus Trichoderma atroviride by HS-SPME-GCMS. Journal of Microbiological Methods 81, 187-193.

Sturz AV, Nowak J. 2000 - Endophytic communities of rhizobacteria and the strategies required to create yield enhancing associations with crops. Applied Soil Ecology 15, 183-190.

Suryanarayanan T, Kumar V. 2000 - Endophytic fungi of some halophytes from an estuarine mangrove forest. Mycological Research 104, 1465-1467.

Suryanarayanan TS, Venkatesan G, Murali TS. 2003 - Endophytic fungal communities in leaves of tropical forest trees: diversity and distribution patterns. Current Science 85, 489-493.

Toju H, Yamamoto S, Sato H, Tanabe AS et al. 2013 - Community composition of root- associated fungi in a Quercus dominated temperate forest: "Codominance" of mycorrhizal and rootendophytic fungi. Ecology and Evolution 3, 1281-1293.

Vogl A. 1898 - Mehl und die anderen Mehlprodukte der Cerealien und Leguminosen. Z. Nahrungs- mittel-Untersuchung, Hyg. Warenkunde 12, 25-29.

Wearn JA, Sutton BC, Morley NJ, Gange AC. 2012 - Species and organ specificity of fungal endophytes in herbaceous grassland plants. Journal of Ecology 100, 1085-1092.

White JF. 1987 - Widespread distribution of endophytes in the Poaceae. Plant Disease 71, 340342.

Yokoya K, Postel S, Fang R, Sarasan V. 2017 - Endophytic fungal diversity ofFragaria vesca, a crop wild relative of strawberry, along environmental gradients within a small geographical area. PeerJ 21, 1-21

Zhang R, Li P, Zhao J, Shan T et al. 2010 - Endophytic fungi from Dioscorea zingiberensis and their effects on the growth and diosgenin production of the host plant cultures. Natural Product Research and Development 22, 11-15. 